\title{
Free Volatile Compounds of cv. Pedro Giménez (Vitis vinifera L.) White Grape Must Grown in San Juan, Argentina
}

\author{
Y.P. Maturano ${ }^{1,2^{*}}$, M.C. Nally, ${ }^{1,2}$, M.V. Assof ${ }^{3}$, M.E. Toro $^{1}$; L.I. Castellanos de Figueroa ${ }^{2,4}$, V. P. Jofré ${ }^{3}$, F. Vazquez
}

(1) Instituto de Biotecnología - Universidad Nacional de San Juan (UNSJ). Av. San Martín 1109 (O) 5400 San Juan, Argentina

(2) Consejo Nacional de Investigaciones Científicas y Técnicas (CONICET) Av. Rivadavia 1917 CABA. Buenos Aires, Argentina

(3) Laboratorio de Aromas y Sustancias Naturales, Estación Experimental Agropecuaria Mendoza, Instituto Nacional de Tecnología Agropecuaria (EEA- INTA), San Martín 3853, 5507 Luján de Cuyo, Mendoza, Argentina

(4) Planta Piloto de Procesos Industriales Microbiológicos (PROIMI) Av. Belgrano y Pasaje Caseros, 4000 Tucumán, Argentina

Submitted for publication: March 2017

Accepted for publication: September 2017

Keywords: Aroma profile, grape must, Pedro Giménez, Argentina

\begin{abstract}
The free aromatic composition of must from Pedro Giménez grapes, grown in San Juan, Argentina, was characterised. Samples from the vintages of 2008 and 2009 were analysed by gas chromatography-mass spectrometry-solid phase microextraction (GC-MS-SPME). Higher alcohols, terpenes, $\mathrm{C}_{13}$-norisoprenoids, esters, aldehydes and ketones were quantified. The calculation of the odour activity values (OAVs) revealed that $\beta$-damascenone, $\alpha$-ionone, $\beta$-linalool, geraniol, ethyl butanoate, hexanoate and octanoate were the most prevalent aroma-active compounds of the grape variety. However, the remaining 42 aromatic compounds that registered OAVs less than 1 could potentially contribute to the flavour of Pedro Giménez grapes. The measured monoterpene levels indicate that the Pedro Giménez grape can be considered a neutral variety. This is the first report describing the main potential free aroma contributors of Pedro Giménez grapes in two consecutive years.
\end{abstract}

\section{INTRODUCTION}

Aroma is one of the most important parameters when determining the character, typicity and quality of wines. Over the past decades there has been an increasing demand by consumers for wines with a fresh and fruity aroma (Zalacain et al., 2007; Hellín et al., 2010).

It is well known that secondary metabolites of grapes constitute the principal aroma compounds in grape must and provide the basis for the varietal character (Boido et al., 2003). Several studies on the volatile compounds of different grape varieties have established a relationship between the wine varietal character and grape compounds (Coelho et al., 2006; Ibarz et al., 2006). These volatile compounds, commonly known as "primary aroma" or "varietal aroma", include mainly terpenes, $\mathrm{C}_{13}$-norisoprenoids, higher alcohols, aldehydes, ketones and esters (Sánchez-Palomo et al., 2006; 2007; Nasi et al., 2008; Yang et al., 2009). Grape aroma compounds are present as free forms, which may contribute directly to odour, and at higher concentrations than nonvolatile sugar-bound conjugates (Sánchez-Palomo et al., 2006). Primary aromas are important because they play a key role in the differentiation of wines according to grape varieties used in winemaking (Zalacain et al., 2007).

The contribution of volatile compounds to odour depends on their threshold and the ratio between their concentration and the threshold, known as "odour activity value" (OAV). This measure allows an estimation of the contribution of each compound to the total aroma composition of wine. Nevertheless, as odour thresholds are affected by additive and synergic effects (Genovese et al., 2013), the odour of a compound can also be described by several descriptors (Ferreira et al., 2002). The OAV is considered the only way to identify the most powerful odorants, even if it is not a true measure of the aromas of grapes and wine (Genovese et al., 2013). Escudero et al. (2004) reported the difficulty of understanding the aromatic structure of complex aromas in which compounds with a high OAV can play a minor role in the flavour composition, whereas compounds with a relatively low OAV can act as impact odorants. Odorants with low OAV, or low-impact odorants (i.e. values typically $\leq 1$ ) are generally considered insignificant to global sensory perception. However, these compounds have the potential to play a critical role in the total odour characterisation of a sample. Furthermore, several authors have presented evidence that compounds with relatively low OAVs can act as significant impact odorants (Escudero et al., 2004; Ryan et al., 2008). It is therefore important to consider all aromatic

\footnotetext{
*Corresponding author: E-mail address: paolamaturano@yahoo.com.ar [Tel.: +54-0264-4211700; Fax: +54-0264-4213672]

Acknowledgements: The authors wish to thank Bodega Augusto Pulenta S.A., for providing the grape must, and the CICITCA-UNSJ and PAE-PICT-2007-02359 projects, for their financial support
} 
compounds present in a matrix under study.

Vitis vinifera L. cv. Pedro Giménez is considered indigenous to Argentina and is the most widely grown white grape variety in the country (87966.1 tons of grapes - 2016 vintage) (Instituto Nactional de Vitivinicultura [INV], 2016). The Argentine National Institute of Viticulture has recognised Pedro Giménez as a suitable grape variety to produce highquality blends as well as monovarietal wines (Law No25.163). It is an important grape variety to the region because it has adapted well to the arid local conditions. Pedro Giménez is a variety that produces wines with intense fruity aromas such as those of apple and pear (Gil \& Pszczòlkowski, 2007). Ampelographic differences allow distinction between the Argentine Pedro Giménez varietal and the Spanish Pedro Ximénez varietal (Hidalgo \& Candela, 1971; Alcalde 1989; Gil \& Pszczòlkowski, 2007).

The flavour compounds of Pedro Giménez grapes have not been identified and quantified yet. A better understanding of the aromatic composition may assist winemakers in the control of the quality of the product, because analysis of the primary aromatic composition is a preliminary stage in the collection of the structural data of wines. Rosillo et al. (1999) have reported numerous conventional methods for the analysis of volatile compounds in grape juice. Some techniques, such as extraction, distillation and simultaneous distillation-extraction, involve the preparation of samples prior to chromatographic analysis. However, these methods are time consuming and involve excessive manipulation of the sample, which may lead to serious errors. The headspace technique allows analysis of the volatile fraction directly from the sample. Good reproducibility has made this technique reliable for the analysis of grape juice (Souid et al., 2007; González-Más et al., 2009). GC-MS is an effective method to analyse the principal volatile compounds of grape juice. This technique reduces the financial cost and contamination (it is solvent-free and only requires vials, septa, caps and fibres) during the extraction of volatile organic compounds (VOCs) from the matrix compared to conventional techniques. In addition, GC-MS provides a less complicated and time-consuming analysis, while retaining high efficiency (González-Más et al., 2009).

The aim of the present study was to examine the free volatile composition of grape must of the Pedro Giménez grape variety grown in San Juan, Argentina, using gas chromatography-mass spectrometry-solid phase microextraction (GC-MS-SPME).

\section{MATERIALS AND METHODS \\ Samples}

Vitis vinifera L. cv. Pedro Giménez grapes were collected from the Doña Filomena vineyard (3132'29' $S$, $68^{\circ} 05^{\prime} 43^{\prime \prime} \mathrm{W}$, at an altitude of $1647 \mathrm{~m}$, in the region of San Martín-San Juan, Argentina) and harvested during the 2008 and 2009 vintages $\left(28^{\circ} \mathrm{Brix}\right.$ and $23^{\circ} \mathrm{Brix}$ respectively). Time of harvest was determined by the ${ }^{\circ} \mathrm{Brix} /$ volatile acidity ratio (Ribereau-Gayon et al., 2000). According to the A.E.R.-San Martín-I.N.T.A. (Agencia de Extensión Rural-San MartínInstituto Nacional de Tecnología Agropecuaria) weather station, which is closest to the plot sampled $(10.3 \mathrm{~km})$, the average monthly temperature and rainfall registered during the period from January to March in 2008 and 2009 was $24.5^{\circ} \mathrm{C}$ and $32.7 \mathrm{~mm}$ and $26^{\circ} \mathrm{C}$ and $16.13 \mathrm{~mm}$ respectively.

Pedro Giménez grapes were hand harvested during the early morning hours, placed in in $20 \mathrm{~kg}$ plastic boxes and chilled to $10^{\circ} \mathrm{C}$ during transportation. Berries were manually removed from the rachis, crushed and pressed. The grape juice was filtered immediately $(0.2 \mu \mathrm{m}$ pore size filter $)$ and three samples of each vintage were conserved in $15 \mathrm{~mL}$ Falcon tubes and stored at $-18^{\circ} \mathrm{C}$ until analysis. Samples were thawed at room temperature and centrifuged at $2133 \mathrm{~g}$ for $5 \mathrm{~min}$.

\section{Headspace-solid-phase microextraction (HS-SPME)}

Samples $(5000.0 \mu \mathrm{L})$ and $4975.0 \mu \mathrm{L}$ pure water (Millipore, Brazil) were poured into $20 \mathrm{~mL}$ glass vials. $\mathrm{NaCl}(3 \mathrm{~g})$ and $25 \mu \mathrm{L}$ of a $25 \mathrm{ng} / \mu \mathrm{L}$ methanolic $R$-2-octanol solution (internal standard) were added to each sample. Vials were sealed with a Teflon-faced septum cap and mixed at $1100 \mathrm{rpm}$ using a magnetic stirrer (IKA, USA). Samples were preconditioned at an extraction temperature of $40^{\circ} \mathrm{C}$ for $15 \mathrm{~min}$. Polydimethylsiloxane/divinylbenzene (PDMS/DVB) fibres (65 $\mu \mathrm{m}$; Supelco, USA) were used for HS-SPME. Prior to exposure, the fibres were conditioned according to the manufacturer's instructions. After pre-conditioning of the sample, SPME fibres $(2 \mathrm{~cm})$ were exposed to the headspace for $15 \mathrm{~min}$ at controlled temperature $\left(40^{\circ} \mathrm{C}\right)$ during the extraction process and, immediately afterwards, they were inserted into the $\mathrm{GC}$ injector port $\left(230^{\circ} \mathrm{C}\right)$ for $20 \mathrm{~min}$ for thermal desorption of the volatile compounds (Massera et al., 2012, Maturano et al., 2015).

\section{Chromatographic conditions}

A Varian CP-3800 gas chromatograph (GC) equipped with a splitless injector and a Saturn 2200 Ion Trap Mass Spectrometer (Varian, Walnut Creek, CA, USA) was used to measure the volatile compounds. The system was operated with Saturn GC-MS Workstation software Version 6.41. The GC was equipped with a Factor Four VF5 column (30 m $\times$ $0.25 \mathrm{~mm} ; 0.25 \mu \mathrm{m}$ film thickness (Varian-CA-USA)). The oven temperature was initially programmed at $40^{\circ} \mathrm{C}(5 \mathrm{~min})$, followed by a gradual increase of $1.5^{\circ} \mathrm{C} / \mathrm{min}$ until $100^{\circ} \mathrm{C}(1$ $\mathrm{min})$, and $3^{\circ} \mathrm{C} / \mathrm{min}$ until $215^{\circ} \mathrm{C}(5 \mathrm{~min})$. Helium was used as carrier gas at a constant flow rate of $1.0 \mathrm{~mL} / \mathrm{min}$. The 1079 injector was maintained at $230^{\circ} \mathrm{C}$. The electron impact energy was $70 \mathrm{eV}$. The temperature of the transfer line and ion trap was $200^{\circ} \mathrm{C}$. Mass spectra of the compounds were compared with the Nist Mass Spectral Library (Nist Mass Spectral Search Program Version 2.0), considering a forward match (FM) equal to or greater than 700 . The identification of volatile compounds was carried out by comparing them with the retention times and the mass spectra from the Nist 2.0 Library. Compounds were quantified using relative areas related to the internal standard (Massera et al., 2012; Maturano et al., 2015).

\section{Odour activity values (OAVs)}

The contribution of each volatile compound to the grape aroma was evaluated qualitatively via its associated descriptor and quantitatively via its OAV. OAVs were calculated by using the equation $\mathrm{OAV}=\mathrm{c} / \mathrm{t}$, where $\mathrm{c}$ is the total concentration of each compound in the grape samples and the odour threshold of the compound in water (Hellín et al., 2010). 
Odour thresholds were calculated according to McGill et al. (1974), Fazzalari (1978), Ohloff (1978), Buttery et al. (1988; 1990), Zalacain et al. (2007) and Hellín et al. (2010).

\section{Statistical analysis}

Each assay was performed independently in triplicate and the results represent the average of the three determinations with the corresponding standard deviation $( \pm$ SD). Experimental data were analysed with ANOVA (SPSS version 19.0). The results were considered significant if the associated $p$ value was $<0.05$.

\section{RESULTS AND DISCUSSION}

It is important to mention the difficulty of understanding the aromatic structure of a complex matrix in which compounds with high or low OAVs can play a minor role, whereas compounds with a relatively low OAV can act as impact odorants. Therefore, in the present work, aromas with low OAVs (between 0.1 and 1) were also considered. These compounds are perceived during wine tasting even at low concentrations because of synergistic and antagonistic effects (Winterhalter \& Rouseff, 2002).

Mean values of the aroma compound concentrations and their respective standard deviations are reported in Table 1. Higher alcohols and terpenes were predominant and together represented $76.32 \%$ and $79.11 \%$ of the total free varietal volatiles in 2008 and 2009 respectively (Table 1, Fig. 1).

Higher alcohols may be present in healthy grapes, but they are seldom present at high levels (Zalacain et al., 2007). In both vintages, $\mathrm{C}_{6}$-alcohols were identified as cis3-hexen-1-ol, trans-3-hexen-1-ol and 1-hexanol (Table 1). These compounds are always present in grapes and their concentration increases during the ripening of grapes (Zalacain et al., 2007), or during maceration and skin contact prior to fermentation (Baumes et al., 1989). Alcohols with six carbon atoms contribute to the "vegetal" and "herbaceous" nuances of wine, but they usually negatively affect the wine quality at concentrations below their OAVs (Gómez García-Carpintero et al., 2011). In the current study they were present at concentrations lower than their OAVs. These compounds seem to be sufficiently stable and remain unaffected by the metabolic activity of yeasts during fermentation (Oliveira et al., 2006). Consequently, the ratio between trans- and cis-3-hexen-1-ol contents could be considered characteristic of each $V$. vinifera variety (Versini et al., 1994). In particular, cis-3-hexen-1-ol was higher than its trans form in all samples from the two vintages assayed (the trans-3-hexenol/cis-3-hexenol ratio in 2008 was 0.87 and in 2009 it was 0.82). Other cultivars, such as Garganega (Moret et al., 1984), Müller-Thurgau (Rapp \& Marais, 1993; Nicolini et al., 1996), Gewürztraminer (Versini et al., 1990), Bacchus (Rapp \& Marais, 1993) and Muscat d'Alexandrie (Aubert et al., 1997) have shown to have a predominance of the trans-3-hexen-1-ol form. In contrast, the Riesling, Kerner, Scheurebe and Ehrenfelser (Rapp \& Marais, 1993), as well as Godello (Versini et al., 1994), Tannat (Boido et al., 2003), Airén (Pérez-Coello et al., 2000), Emir (Cabaroglu et al., 1997) and Bobal (Gómez García-Carpintero et al., 2011) cultivars presented trans-3-hexenol/cis-3-hexenol ratios lower than 1. In addition, 1-hexanol/trans-3-hexenol and 1-hexanol/cis-3-hexenol ratios could also be employed to characterise the grape variety. The grape musts analysed in this study exceeded ratios over 1.

The presence of 1-hexanol, cis-3-hexenol and the transisomer may be attributed to the specificity of enzymes involved in the sequence of $\mathrm{C}_{6}$-alcohol formation. The composition of the $\mathrm{C}_{6}$ compounds depends strongly on four enzymes, which catalyse the biosynthesis of these compounds. Among these four, lipoxygenase and hydroperoxide lyase are particularly important (Gómez García-Carpintero et al., 2011; Boido et al., 2003). Thus, the levels of these compounds and the ratios between them could be considered characteristic of each $V$. vinifera variety.

The benzene alcohol fraction was composed of benzyl

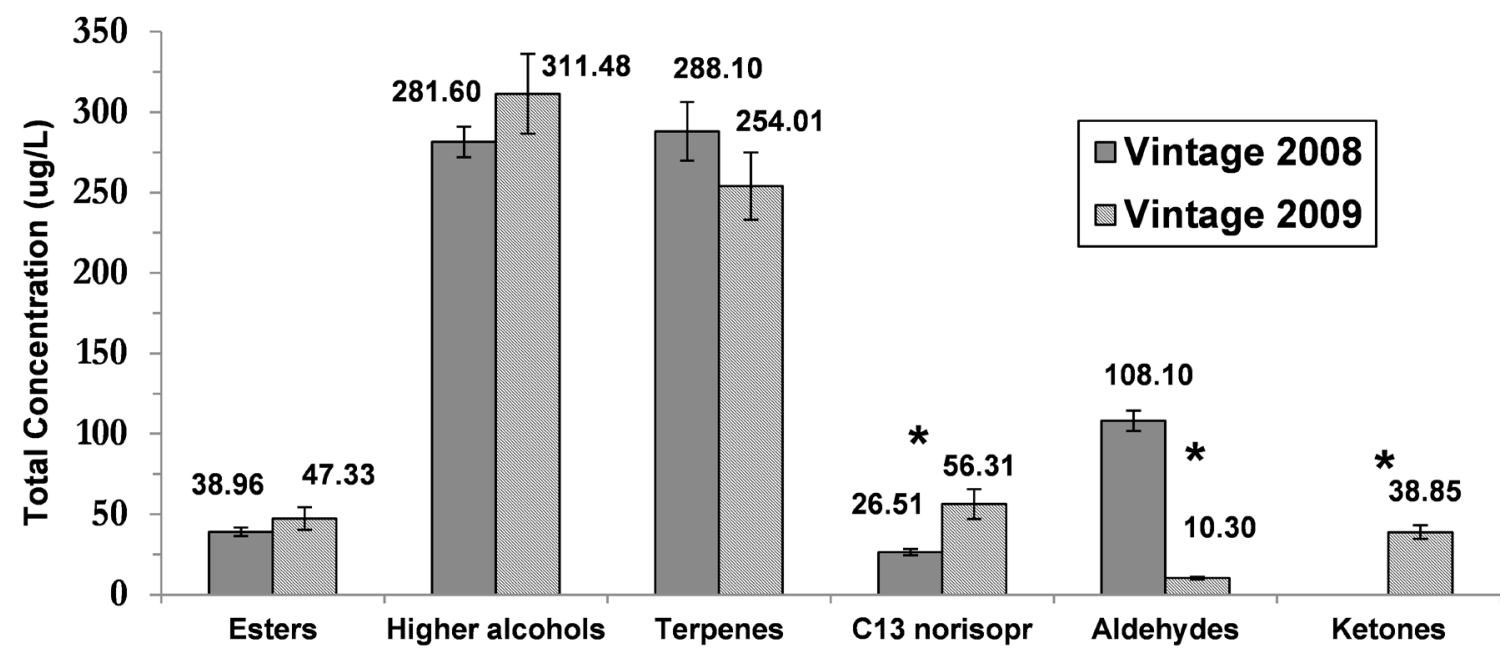

FIGURE 1

Total concentration of different groups of volatile compounds determined in Pedro Giménez must (2008 and 2009 vintages): esters, higher alcohols, terpenes, $\mathrm{C}_{13}$-norisoprenoids, aldehydes and ketones. Data are means \pm standard deviation of three replicates. * Significant differences between 2008 and 2009 vintages. 
TABLE 1

Odour-active compounds in Pedro Giménez grape must (2008 and 2009 vintages).

\begin{tabular}{|c|c|c|c|c|c|c|c|}
\hline & Aromatic compounds & Odour descriptor & $\begin{array}{l}\text { Odour } \\
\text { threshold } \\
(\mu \mathrm{g} / \mathrm{L})\end{array}$ & $\begin{array}{l}2008 \text { Must } \\
(\mu \mathrm{g} / \mathrm{L})\end{array}$ & $\begin{array}{l}2009 \text { Must } \\
(\mu \mathrm{g} / \mathrm{L})\end{array}$ & OAV 2008 & OAV 2009 \\
\hline \multirow{9}{*}{$\underset{0}{\mathscr{a}}$} & Ethyl butanoate & Banana, pineapple & $1^{\mathrm{a}}$ & $7.5 \pm 0.9$ & $9.23 \pm 0.07$ & $7.5^{*}$ & $9.23 *$ \\
\hline & Ethyl hexanoate & Green apple & $1^{\mathrm{a}}$ & $6.44 \pm 0.3$ & $8.61 \pm 2.02$ & $6.44 *$ & $8.61 *$ \\
\hline & Ethyl octanoate & Sweet, fruity & 15 & $14.98 \pm 0.5$ & $18.04 \pm 4.27$ & $1 *$ & $1.20 *$ \\
\hline & 2-Phenylethyl acetate & Roses, flowery & $650^{\mathrm{a}}$ & ND & $5.85 \pm 0.57$ & & 0.009 \\
\hline & Methyl 2-methyl pentanoate & Fruity, strawberry & & $3.89 \pm 0.27$ & ND & & \\
\hline & 2-Methyl ethyl propanoate & Sweet, fruity & $0.1^{\mathrm{a}}$ & $3.31 \pm 0.45$ & ND & & \\
\hline & Ethyl hexadecanoate & & $>2000^{\mathrm{a}}$ & $5.83 \pm 0.23$ & ND & 0.0029 & \\
\hline & Isopropyl myristate & & & ND & $5.59 \pm 0.09$ & & \\
\hline & Total & & & 38.96 & 47.33 & & \\
\hline \multirow{11}{*}{ 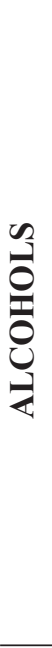 } & 2-Methyl-1-butanol & Fruity & $500^{\mathrm{a}}$ & $30.93 \pm 3.5$ & ND & 0.061 & \\
\hline & 3.4-Dimethyl-pentanol & & & $40.18 \pm 2.78$ & ND & & \\
\hline & Trans-3-hexen-1-ol & Green & $1000^{\mathrm{a}}$ & $11.16 \pm 0.01$ & $15.64 \pm 0.36$ & 0.011 & 0.016 \\
\hline & cis-3-hexen-1-ol & Green & $70^{\mathrm{a}, \mathrm{c}}$ & $12.71 \pm 1.2$ & $19 \pm 2.31$ & $0.18 * * *$ & $0.27 * * *$ \\
\hline & 3-Methyl-2-hexanol & Green & & ND & $10.25 \pm 1.34$ & & \\
\hline & 1-hexanol & Green & $270000^{\mathrm{a}}$ & $47.38 \pm 0.45$ & $104.59 \pm 6.92$ & $<0.0001$ & $<0.0001$ \\
\hline & 2-Phenylethanol & Rose & $750^{\mathrm{a}, \mathrm{b}}$ & $95.66 \pm 0.9$ & $101.8 \pm 21.75$ & $0.11 * * *$ & $0.135^{* * *}$ \\
\hline & 1-Octen-3-ol & Mushroom & $1^{\mathrm{a}}$ & $38.71 \pm 0.2$ & $41.07 \pm 1.58$ & $38.71 *$ & $41.07^{*}$ \\
\hline & 1-Nonanol & Fatty, floral & $50^{\mathrm{a}}$ & ND & $19.38 \pm 0.6$ & $0.38 * * *$ & \\
\hline & Benzyl alcohol & Walnut & $10000^{\mathrm{a}, \mathrm{b}}$ & $4.62 \pm 0.45$ & ND & 0.0046 & \\
\hline & Total & & & 281.6 & 311.48 & & \\
\hline \multirow{16}{*}{ 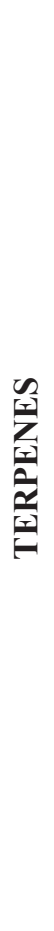 } & Limonene & Citrus & $10^{\mathrm{a}}$ & $1.14 \pm 0.1$ & $0.95 \pm 0.17$ & $0.114^{* * *}$ & $0.095 * * *$ \\
\hline & Eucalyptol & Eucalyptus & $12^{\mathrm{a}}$ & ND & $8.97 \pm 1.72$ & $0.75^{* *}$ & \\
\hline & cis-Linalool oxide & Fresh, pine, flower & $>3000^{\mathrm{b}}$ & $35.29 \pm 0.3$ & $8.48 \pm 0.11$ & 0.011 & 0.0028 \\
\hline & $\beta$-Linalool & Orange flower & $6^{\mathrm{a}, \mathrm{b}}$ & $49.34 \pm 3.2$ & $148.25 \pm 17.7$ & $8.22 *$ & $24.71 *$ \\
\hline & Hotrienol & & $110^{\mathrm{a}}$ & $14.38 \pm 1.2$ & ND & $0.144 * * *$ & \\
\hline & trans-Rose oxide & Flower, rose & $0.5^{\mathrm{a}}$ & $0.62 \pm 0.03$ & ND & $1.24 *$ & \\
\hline & 1-Menthol & Minty & & $40.94 \pm 2.45$ & $10.10 \pm 1.8$ & & \\
\hline & $\alpha$-Terpineol & Anise & $330^{\mathrm{a}, \mathrm{b}}$ & $29.28 \pm 0.9$ & $34.90 \pm 3.81$ & $0.091 * * *$ & $0.1 * * *$ \\
\hline & Borneol & & & $1.09 \pm 0.06$ & ND & & \\
\hline & cis-Limonene oxide & & & $2.42 \pm 0.1$ & ND & & \\
\hline & Citronellol & Citrus & $40^{\mathrm{a}, \mathrm{b}}$ & $23.38 \pm 0.9$ & ND & $0.58 * *$ & \\
\hline & Geraniol & Geranium & $40^{\mathrm{a}, \mathrm{b}}$ & $65.25 \pm 7.4$ & $38.2 \pm 5.6$ & $1.63 *$ & $0.96^{*}$ \\
\hline & Carvone & & $50^{\mathrm{a}}$ & $5.33 \pm 0.6$ & ND & $0.11 * * *$ & \\
\hline & cis-Geranyl acetone & & $60^{\mathrm{a}}$ & $13.58 \pm 0.34$ & $13.12 \pm 0.04$ & $0.23 * * *$ & $0.22 * * *$ \\
\hline & Isobornyl acetate & & 75 & $6.02 \pm 0.72$ & ND & 0.08 & \\
\hline & Total & & & 288.1 & 254.01 & & \\
\hline
\end{tabular}




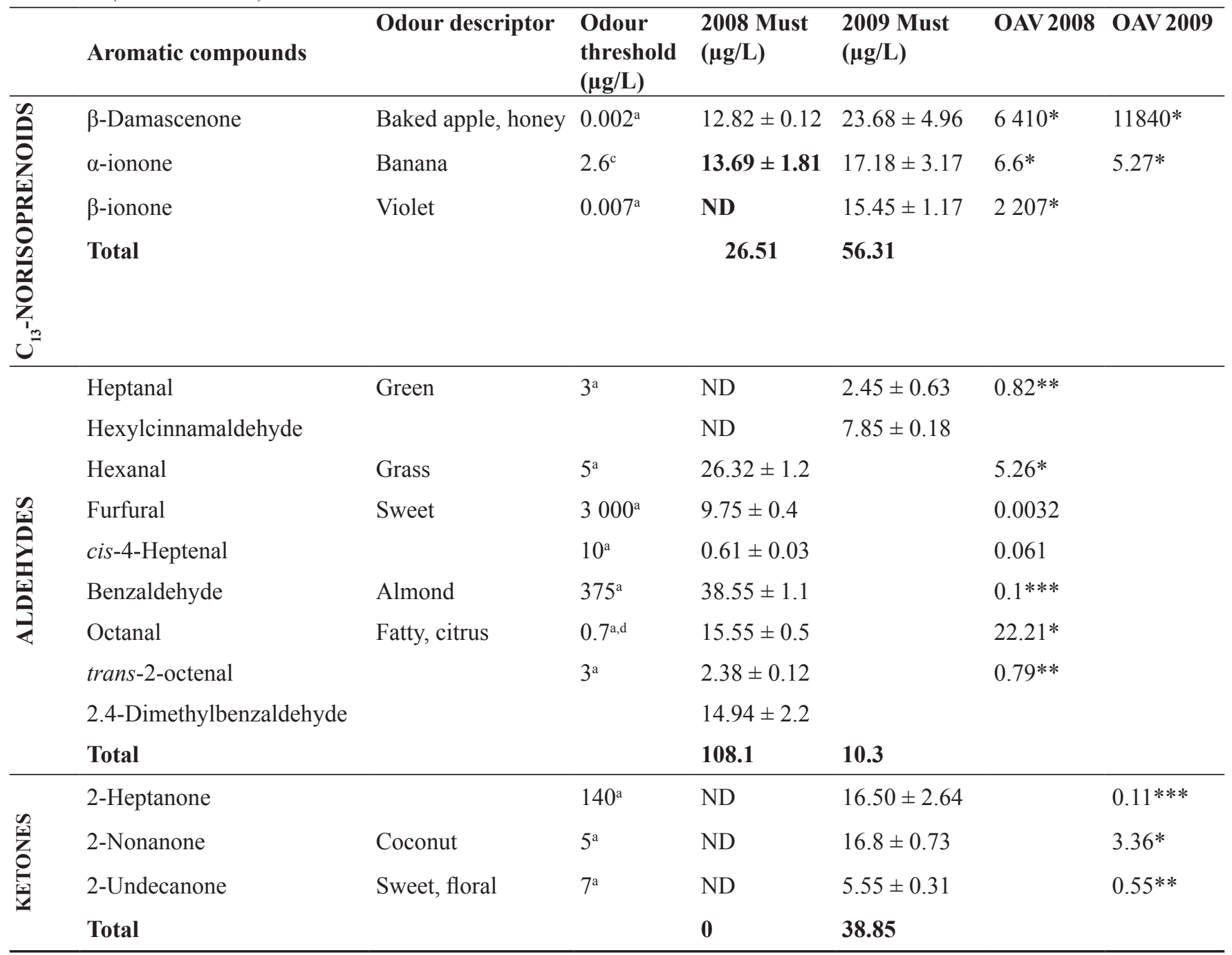

$\mathrm{ND}=$ Not detected

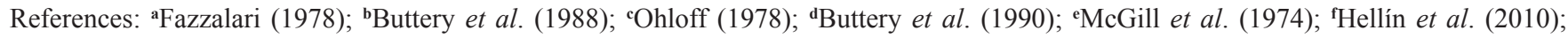
'Zalacain et al. (2007)

Shaded values indicate significantly different values between the 2008 and 2009 musts

*OAV $>1 ; * * 0.5<\mathrm{OAV}<1 ; * * * 0.1<\mathrm{OAV}<0.5$

alcohol $(4.62 \pm 0.45 \mu \mathrm{g} / \mathrm{L}$, only present in grapes harvested during the 2008 vintage) and 2-phenylethanol, with registered values of $95.66 \pm 0.9$ and $101.8 \pm 21.75 \mu \mathrm{g} / \mathrm{L}$ in the 2008 and 2009 harvests respectively. In spite of registered OAVs lower than 1 (Table 1), these compounds could add a synergistic effect to wine aroma with fruity and floral notes (Gómez García-Carpintero et al., 2011). Considering other white varieties, Diéguez et al. (2003) reported significantly higher values of benzyl alcohol and 2-phenylethanol using C18 cartridges and GC-MS. On the other hand, Sánchez Palomo et al. (2007) found similar values for 2-phenylethanol in Muscat "à Petit Grains", but significantly higher values for benzyl alcohol analysed by GC/FID/MS.

Another alcohol, 1-octen-3-ol, was present in must samples of both vintages and exceeded the perception threshold (Table 1). This compound is quantitatively important because it is responsible for the mushroom odour in certain wines (Fazzalari, 1978). It is a typical by-product of the metabolic activity of certain filamentous fungi from the genera Botrytis, Aspergillus, Penicillium, Fusarium and Alternaria, and various Ascomycetes and Basidiomycetes yeasts (La Guerche et al., 2006; Rousseaux et al., 2014). In the present study, the grapes were probably infected by yeasts or fungi before they were harvested. However, their concentration must have been too low to be visible with the naked eye (e.g. Botrytis), because the grapes seemed to be in a good sanitary condition. The contaminants could have appeared through mismanagement of the vineyard. Lack of aeration could have caused an increase in relative humidity, favouring growing conditions for the contaminants.

Terpene compounds belong to secondary plant constituents, and their biosynthesis begins with acetyl-CoA (Vilanova et al., 2013). The quali-quantitative composition of terpenes is considered strictly related to the origin of the grape (Mateo \& Jiménez, 2000; Câmara et al., 2004; Nasi et al., 2008). A total of 15 terpenoids were identified and quantified in Pedro Giménez grape must. Seven of these were present in grapes harvested in both the 2008 and 2009 
vintages: limonene, cis-linalool oxide, $\beta$-linalool, 1-menthol, $\alpha$-terpineol, geraniol and cis-geranyl acetone (Table 1). A larger number of aromatic constituents and a higher total concentration of terpenes were registered in grapes harvested during the 2008 vintage compared to 2009, except for linalool (three times more in 2009) and cis-geranyl acetone (no difference between the 2008 and 2009 samples) (Table 1, Fig. 1). It is well known that the terpene content is affected by several environmental factors, the most important being sunlight (light penetration into the fruiting zone), diurnal temperature and water stress during the developmental and ripening stages of the grapes. Vineyards with lower maximum temperatures are conducive to an increased accumulation of terpenes compared to vineyards with higher maximum temperatures (Câmara et al., 2004).

Monoterpene alcohols like linalool, geraniol, nerol, citronellol and $\alpha$-terpineol are responsible for floral notes in aromatic grape varieties such as Muscat, Riesling, Viognier, Loureiro and Gewürztraminer, but they can also be found in varieties that are not usually considered floral, including Pinot Gris and Chardonnay (Swiegers et al., 2005; Luan et al., 2006; Oliveira e Silva et al., 2008; Vilanova et al., 2013).

Based on the monoterpene levels quantified in the present study, Pedro Giménez can be considered a neutral variety: non-Muscat but aromatic varieties have a total monoterpene concentration of 100 to $400 \mu \mathrm{g} / \mathrm{L}$ (Mateo \& Jiménez, 2000). It is important to highlight that the content of bound volatiles of aromatic grape varieties sometimes reaches levels similar to that of free volatiles (Lamorte et al., 2015). The typical aroma character of wine obtained from these non-aromatic grapes can improve the wine quality because of the transformation of odourless precursors into odour-active compounds during the winemaking process. Non-aromatic grapes can therefore be defined more accurately as potentially aromatic grapes after the transformation of odourless precursors into odouractive compounds (Genovese et al., 2013).

The results obtained in this study show that $\beta$-linalool and geraniol were markedly the most abundant monoterpenes in grapes harvested during 2008 and 2009; $\beta$-linalool exceeded the threshold in both years and geraniol only in 2008 (Table 1). Other compounds, such as $\alpha$-terpineol and citronellol (only present in the 2008 grape must) were present at notable concentrations but below their perception threshold (Table 1). Diéguez et al. (2003) and Câmara et al. (2004) analysed free monoterpenols in white grape varieties and reported values significantly lower than those reported in the present study.

The absence of nerol, a monoterpene alcohol more commonly found in white grapes, is remarkable (Oliveira et al., 2008; Vilanova et al., 2013). A plausible explanation is the transformation of this compound into $\alpha$-terpineol by cyclical reactions at must pH (Mateo \& Jiménez, 2000).

Another class of compounds commonly considered favourable in terms of their aroma descriptor is $\mathrm{C}_{13}$ norisoprenoids. Different authors have reported their presence in grapes and wines in volatile form (Strauss et al., 1987; Williams et al., 1993; Kotseridis et al., 1999; Pedroza et al., 2010). These compounds can be the result of the direct degradation of carotenoid molecules (Genovese et al., 2007).
Three $\mathrm{C}_{13}$ norisoprenoids were detected in the 2008 and 2009 grape must samples. Two of them, $\beta$-damascenone and $\alpha$-ionone, showed concentrations above the odour threshold (Table 1), and their concentration was significantly higher in grapes harvested during the 2009 vintage than during the 2008 vintage (Table 1). This could be attributable to the higher diurnal temperatures in 2009 (Rapp \& Marais, 1993). The high concentration of $\beta$-damascenone and $\alpha$-ionone could be due to the arid climate that characterises the San Juan province. In fact, the high sun exposure and high temperature could induce a faster rate of carotenoid degradation, thereby increasing the $\mathrm{C}_{13}$-norisoprenoid concentration (Razungles et al., 1998; Bureau et al., 2000). Diéguez et al. (2003) and Câmera et al. (2004) reported similar findings for $\beta$-damascenone and $\alpha$-ionone in white grape varieties. The exception was the high values of $\beta$-damascenone detected in the grapes harvested during the 2009 vintage (Table 1).

Esters are formed by the reaction of acetyl-CoA with higher alcohols previously produced after the degradation of amino acids or carbohydrates (Etievant, 1991). Esters in wine mainly originate from yeast metabolism during fermentation, but some esters are also found in small quantities in grape berries (Perestrelo et al., 2006). Only a few esters, present in small quantities in grapes, contribute to the aroma of Vitis vinifera varieties (Vilanova et al., 2013). Four ethyl esters, one acetate and three others esters were detected in this chemical group at concentrations ranging from $3.31 \pm 0.45$ to $18.04 \pm 4.27 \mu \mathrm{g} / \mathrm{L}$ (Table 1 ). Only ethylic esters that contribute to the "fruity aroma" (ethyl butanoate, hexanoate and octanoate) were quantified at levels above their olfactory perception threshold in grapes harvested during the 2008 and 2009 vintages (Table 1). These compounds may play a major sensory role, especially in neutral grape varieties containing relatively low quantities of terpenes (Sánchez Palomo et al., 2007). Furthermore, as olfactory notes are similar, a synergic effect has been reported (Vilanova et al., 2013). Few studies have reported the presence of esters in grape juice (Baek et al., 1997; Swiegers et al., 2005).

Carbonyl compounds, such as hexanal, heptanal and ketones, derived from acetaldehyde, have been associated with herbaceous and rancidity odours and their origin has been reported to be correlated with lipoxygenase activity in the grape and/or must aeration (Zalacain et al., 2007). Aldehydes were quantified in grapes harvested during both the 2008 and 2009 vintages, but the concentration in grape juice was approximately tenfold higher in 2008 than in 2009 (Table 1, Fig. 1). According to Hardy (1970), this phenomenon may be related to the concentration of sugars in mature grapes. Ketones were only detected in the 2009 must samples, and always at concentrations below the odour threshold, except for 2-nonanone, which was above the threshold value (Table 1). Their concentrations may be affected by environmental factors such as elevated temperature and water stress during the ripening stages of the grapes (Sánchez-Palomo et al., 2007).

It is important to highlight that, in complex matrices such as grape juice or wine, the diversity of the reported sensory perceptions is the result of qualitative (odour quality) and quantitative (odour intensity) perceptual interactions between odorants. These interactions have been defined by several 
authors in different ways. However, perceptual interactions between multiple volatile components remain difficult to predict in a complex matrix such as grape juice or wine, in which the overall perception cannot be predicted solely by the sum of perceptions of individual compounds (Lytra et al., 2012). In order to fully evaluate the importance of low-impact odorants and better understand the complexities of global odour perception, an innovative multidisciplinary approach is needed to incorporate chemical, sensory and neurological studies. A follow-up study contemplates sensorial analysis, proposing omission or addition tests in a reconstituted must mixture in order to rank the importance of individual compounds.

\section{CONCLUSIONS}

This is the first study that characterises the free aromatic compound profile of Pedro Giménez grape must. Higher alcohols, terpenes, $\mathrm{C}_{13}$-norisoprenoids, esters, aldehydes and ketones from musts of the 2008 and 2009 vintages were quantified by GC-MS. The monoterpene levels registered indicate that Pedro Giménez grape must can be considered a neutral variety.

OAVs of Pedro Giménez grape must compounds demonstrated that $\beta$-damascenone, $\alpha$-ionone, $\beta$-linalool, geraniol, ethyl butanoate, hexanoate and octanoate were the most powerful aroma-active compounds in this variety. However, the remaining 41 aromatic compounds with OAVs less than 1 could also contribute to the flavour of Pedro Giménez. Our results, from two consecutive vintages, provide valuable information about potential Pedro Giménez varietal compounds that greatly contribute to the aroma.

Because the analysis of aromatic glycoconjugate-bound compounds was not included in this study, these chemicals could be incorporated into future studies in order to establish a complete aromatic profile of this autochthonous variety.

\section{LITERATURE CITED}

Alcalde, A.J., 1989. Cultivares vitícolas argentinas. INTA, Mendoza, Argentina.

Aubert, C., Baumes, R., Gunata, Z., Lepoutre, J.P., Cooper, J.F. \& Bayonove, C., 1997. Effects of flusilazole, a sterol biosynthesis inhibitor fungicide, on the free and bound aroma fraction of Muscat of Alexandria wines. J. Int. Sci. Vigne Vin. 31, 57-64.

Baek, H.H., Cadwallader, K.R., Marroquin, E. \& Silva, J.L., 1997. Identification of predominant aroma compounds in Muscadine grape juice. J. Food Sci. 62, 249- 252

Baumes, R., Bayonove, C., Barillere, J.M., Escudier, J.L. \& Cordonnier, R.E., 1989. La macération pelliculaire dans la vinification en blanc. Incidence sur la composante volatile des vins. Vitis 28, 31-48.

Boido, E., Lloret, A., Medina, K., Fariña, L., Carrau, F., Versini, G. \& Dellacassa, E., 2003. Aroma composition of Vitis vinifera cv. Tannat: The typical red wine from Uruguay. J Agric. Food Chem. 51, 5408-5413.

Bureau, S.M., Baumes, R.L. \& Razungles, SA.J., 2000. Effects of vine or bunch shading on the glycosylated flavor precursors in grapes of Vitis vinifera L. Cv. Syrah. J. Agric. Food Chem. 48, 1290-1297.

Buttery, R.G., Teranishi, R., Ling, L.C. \& Turnbaugh, J.G., 1990. Quantitative and sensory studies on tomato paste volatiles. J. Agric. Food Chem. 38, 336-340.
Buttery, R.G., Turnbaugh, J.G. \& Ling, L.C., 1988. Contribution of volatiles to rice aroma. J. Agric. Food Chem. 36, 1006-1009.

Cabaroglu, T., Canbas, A., Baumes, R., Bayonove, C., Lepoutre, J.P. \& Günata, Z., 1997. Aroma composition of a white wine of Vitis vinifera L. cv. Emir as affected by skin contact. J. Food Sci. 62, 680-683.

Câmara, J.S., Herbert, P., Marques, J.C. \& Alves, M.A., 2004. Varietal flavour compound of four grape varieties producing Madeira wines. Anal. Chem. Acta 513, 203-207.

Coelho, E., Rocha, S.M., Delgadillo, I. \& Coimbra, M.A., 2006. HeadspaceSPME applied to varietal volatile components evolution during Vitis vinifera L. cv. 'Baga' ripening. Anal. Chem. Acta 563, 204-214.

Diéguez, S.C., De la Peña, M.L.G. \& Gómez, E.F., 2003. Approaches to spirit aroma: Contribution of some aromatic compounds to the primary aroma in samples of Orujo spirits. J. Agric. Food Chem. 51, 7385-7390.

Escudero, A., Gogorza, B., Melus, M.A., Ortin, N., Cacho, J. \& Ferreira, V., 2004. Characterization of the aroma of a wine from Maccabeo. Key role played by compounds with low odor activity values. J. Agric. Food Chem. 52, 3516-3524

Etievant, P.X., 1991. Wine. In: H. Maarse (ed.). Volatile compounds in foods and beverages. CRC Press, New York. pp. 483 - 546.

Fazzalari, F.A., 1978. Compilation of odor and taste threshold values data. ASTM Data series, DS Serie A.

Ferreira, V., Ortín, N., Escudero, A., López, R. \& Cacho, J., 2002. Chemical characterization of the aroma of Grenache rosé wines: Aroma extract dilution analysis, quantitative determination, and sensory reconstitution studies. J. Agric. Food Chem. 50, 4048-4054.

Gómez García-Carpintero, E., Sánchez-Palomo, E. \& González-Viñas, M.A., 2011. Aroma characterization of red wines from cv. Bobal grape variety grown in La Mancha region. Food Res. Int. 44, 61-70.

Genovese, A., Gambuti, A., Piombino, P. \& Moio, L., 2007. Sensory properties and aroma compounds of sweet Fiano wine. Food Chem. 103, $1228-1236$

Genovese, A., Lamorte, S.A., Gambuti, A. \& Moio, L., 2013. Aroma of Aglianico and Uva di Troia grapes by aromatic series. Food Res. Int. 53, $15-23$

Gil, G.F. \& Pszczòlkowski, P., 2007. La vid. In Universidad Católica de Chile (eds). Viticultura fundamentos para optimizar producción y calidad. Chile, Universidad Católica de Chile. pp. 26-75.

González-Mas, M.C., García-Riaño, L.M., Alfaro, C., Rambla, J.L., Padilla, A.I. \& Gutierrez, A., 2009. Headspace-based techniques to identify the principal volatile compounds in red grape cultivars. Int. J. Food Sci. Technol. 44, 510-518.

Hardy, P.J., 1970. Changes in volatiles of muscat grapes during ripening. Phytochemistry 9, 709-715.

Hellín, P., Manso, A., Flores, P. \& Fenoll, J., 2010. Evolution of aroma and phenolic compounds during ripening of "Superior Seedless" grapes. J. Agric. Food Chem. 58, 6334-6340.

Hidalgo, L. \& Candela, M.R., 1971. Contribución al conocimiento del inventario vitícola nacional. I.N.I.A., Madrid, Spain.

Ibarz, M.J., Ferreira, V., Hernández-Orte, P., Loscos, N. \& Cacho, J., 2006. Optimization and evaluation of a procedure for the gas chromatographicmass spectrometric analysis of the aromas generated by fast acid hydrolysis of flavor precursors extracted from grapes. J. Chromatogr. A 1116, 217-229.

Instituto Nacional de Vitivinicultura (INV), 2016. Estadisticas/cosecha y elaboración [Online]. http://www.inv.gov.ar/inv contenidos/pdf/ estadisticas/Cosecha/2016/6-UVA-DESTINADA-VINOS-MOSTOSSEGUN-ORIGEN-VARIEDADES-2016.pdf 
Kotseridis, Y., Baumes, R.L., Bertrand, A. \& Skouroumounis, G.K., 1999. Quantitative determination of $\beta$-ionone in red wines and grapes of Bordeaux using a stable isotope dilution assay. J. Chromatogr. A 848, 317-325.

La Guerche, S., Dauphin, B., Pons, M., Blancard, D. \& Darriet, P., 2006. Characterization of some mushroom and earthy off-odors microbially induced by the development of rot on grapes. J. Agric. Food Chem. 54, 9193-9200.

Lamorte, S.A., Gambuti, A., Genovese, A., Selicato, S. \& Moto, L., 2015. Free and glycoconjugated volatiles of $V$. vinifera grape 'Falanghina'. VITIS - J. Grapevine Res. 47, 241-243.

Lytra, G., Tempere, S., De Revel, G. \& Barbe, J.C., 2012. Impact of perceptive interactions on red wine fruity aroma. J. Agric. Food Chem. 60, 12260-12269.

Massera, A., Assof, M., Sturm, M.E., Sari, S., Jofré, V., Cordero-Otero, R. \& Combina, M., 2012. Selection of indigenous Saccharomyces cerevisiae strains to ferment red musts at low temperature. Ann. Microbiol. 62, 367380 .

Mateo, J.J. \& Jiménez, M., 2000. Monoterpenes in grape juice and wines. J. Chromatogr. A 881, 557-567.

Maturano, Y.P., Assof, M., Fabani, M.P., Nally, M.C., Jofré, V., Assaf, L.A.R. \& Vazquez, F., 2015. Enzymatic activities produced by mixed Saccharomyces and non-Saccharomyces cultures: Relationship with wine volatile composition. Antonie van Leeuwenhoek 108, 1239-1256.

McGill, A.S., Hardy, R., Burt, R.J. \& Gunstone, F.D., 1974. Hept-cis-4-enal and its contribution to the off-flavour in cold stored cod. J. Sci. Food Agri. $25,1477-1489$.

Moret, I., Scarponi, G. \& Cescon, P., 1984. Aroma components as discriminating parameters in the chemometric classification of Venetian white wines. J. Sci. Food Agri. 35, 1004-1011.

Nasi, A., Ferranti, P., Amato, S. \& Chianese, L., 2008. Identification of free and bound volatile compounds as typicalness and authenticity markers of non-aromatic grapes and wines through a combined use of mass spectrometric techniques. Food Chem. 110, 762-768.

Nicolini, G., Versini, G., Amadei, E. \& Marchio, M., 1996. 3-hexen-1-ol isomers in Müller-Thurgau wines: A "varietal" characteristic affected by must sulfiting time. Vitis Geilweilerhof 35, 147-148.

Ohloff, G., 1978. Importance of minor components in flavors and fragrances. Perfumer and Flavorist 3, 11-22.

Oliveira, C., Barbosa, A., Ferreira, A.C., Guerra, J. \& Pinho, G.D., 2006. Carotenoid profile in grapes related to aromatic compounds in wines from Douro region. J. Food Sci. 71, S1-S7.

Oliveira e Silva, H., Guedes de Pinho, P., Machado, B.P., Hogg, T., Marques, J.C., Câmara, J.S. \& Silva Ferreira, A.C., 2008. Impact of forced-aging process on Madeira wine flavor. J. Agric. Food Chem. 56, 11989-11996.

Pedroza, M.A., Zalacain, A., Lara, J.F. \& Salinas, M.R., 2010. Global grape aroma potential and its individual analysis by SBSE-GC-MS. Food Res. Int. 43, 1003-1008.

Perestrelo, R., Fernandes, A., Albuquerque, F.F., Marques, J.C. \& Camara, J.S., 2006. Analytical characterization of the aroma of Tinta Negra Mole red wine: Identification of the main odorants compounds. Anal. Chem. Acta $563,154-164$

Pérez-Coello, M.S., Sánchez, M.A., García, E., González-Viñas, M.A., Sanz, J. \& Cabezudo, M.D., 2000. Fermentation of white wines in the presence of wood chips of American and French oak. J. Agric. Food Chem. $48,885-889$.

Rapp, A. \& Marais, J., 1993. The shelf life of wine. Changes in aroma substances during storage and ageing of white wines. In: G. Charalambous (ed.), Shelf life studies of food and beverages. Chemical, biological, physical and nutritional aspects. pp. $891-921$.
Razungles, A., Baumes, R., Dufour, C., Sznaper, C. \& Bayonove, C., 1998. Effect of sun exposure on carotenoid and C13-norisoprenid glycosides in Syrah berries (Vitis vinifera L.) Science des Aliments 18, 361-373.

Ribéreau-Gayon, P., Dubourdieu, D., Donèche, B. \& Lonvaud, A. (eds), 2000. Handbook of enology, the microbiology of wine and vinifications (Vol. 1). John Wiley \& Sons.

Rosillo, L., Salinas, M.R., Garijo, J. \& Alonso, G.L., 1999. Study of volatiles in grapes by dynamic headspace analysis: Application to the differentiation of some Vitis vinifera varieties. J. Chromatogr. A 847, 155-159.

Rousseaux, S., Diguta, C.F., Radoï-Matei, F., Alexandre, H. \& GuillouxBénatier, M., 2014. Non-Botrytis grape-rotting fungi responsible for earthy and moldy off-flavors and mycotoxins. Food Microbiol. 38, 104-121.

Ryan, D., Prenzler, P.D., Saliba, A.J. \& Scollary, G.R., 2008. The significance of low impact odorants in global odour perception. Trends Food Sci. Technol. 19, 383-389.

Rocha, S.M., Coutinho, P., Coelho, E., Barros, A.S., Delgadillo, I., Coimbra, M.A., 2010. Relationships between the varietal volatile composition of the musts and white wine aroma quality. A four year feasibility study. LWTFood Sci. Technol. 43, 1508-1516.

Sánchez-Palomo, E., Díaz-Maroto, M.C., González Viñas, M.A., SorianoPérez, A. \& Pérez-Coello, M.S., 2007. Aroma profile of wines from Albillo and Muscat grape varieties at different stages of ripening. Food Control 18, 398-403.

Sánchez-Palomo, E., Pérez-Coello, M.S., Díaz-Maroto, M.C., González Viñas, M.A. \& Cabezudo, M.D., 2006. Contribution of free and glycosidically-bound volatile compounds to the aroma of muscat "a petit grains" wines and effect of skin contact. Food Chem. 95, 279-289.

Souid, I., Hassen, Z., Sánchez-Palomo, E., Pérez-Coello, M.S. \& Ghorbel, A.W., 2007. Varietal aroma compounds of Vitis vinifera $\mathrm{cv}$. Khamri grown in Tunisia. J. Food Qual. 30, 718-730.

Strauss, C.R., Wilson, B., Anderson, R. \& Williams, P.J., 1987. Development of precursors of $\mathrm{C} 13$ nor-isoprenoid flavorants in Riesling grapes. Am. J. Enol. Vitic. 38, 23-27.

Swiegers, J.H., Bartowsky, E.J., Henschke, P.A. \& Pretorius, I.S., 2005. Yeast and bacterial modulation of wine aroma and flavour. Aust. J. Grape Wine Res. 11, 139-173.

Versini, G., Qrriolsz, I. \& Dalla Serra, A., 1994. Aroma components of Galician Albarifio, Loureira and Godello wines. Vitis 33, 165-170.

Versini, G., Rapp, A., Volkmann, C. \& Scienza, A., 1990. Flavour compounds of clones from different grape varieties. Vitis (Special issue) 513-524.

Vilanova, M., Genisheva, Z., Graña, M. \& Oliveira, J.M., 2013. Determination of odorants in varietal wines from international grape cultivars (Vitis vinifera) grown in NW Spain. S. Afr. J. Enol. Vitic. 34, $212-$ 222

Williams, P.J., Sefton, M.A. \& Marinos, V.A. 1993. Hydrolytic flavor release from non-volatile precursors in fruits, wines and some other plantderived foods. Recent developments in flavor and fragrance chemistry. pp. $283-289$

Winterhalter, P. \& Rouseff, R. (eds), 2002. Carotenoid-derived aroma compounds: An introduction. In: Carotenoid-Derived Aroma Compounds, ACS Symposium Series 802. American Chemical Society, Washington, DC. pp. $1-17$.

Yang, C., Wang, Y., Liang, Z., Fan, P., Wu, B., Yang, L. \& Li, S., 2009. Volatiles of grape berries evaluated at the germplasm level by headspaceSPME with GC-MS. Food Chem. 114, 1106-1114.

Zalacain, A., Marín, J., Alonso, G.L. \& Salinas, M.R., 2007. Analysis of wine primary aroma compounds by stir bar sorptive extraction. Talanta 71 , 1610-1615. 